\title{
Case study of application geotextile tube in the construction of sea dike and shore protection
}

\author{
Eun Chul Shin ${ }^{1, *}$, Sung Hwan $\mathrm{Kim}^{1}$ \\ ${ }^{1}$ Dept. of Civil and Env. Engg., Incheon National Univ., (Songdo-dong)119 Academy-ro, Incheon,22012, Korea \\ * Key-note speaker
}

\begin{abstract}
Recently, because of the shortage of natural rock, traditional forms of the river and coastal structures have become very expensive to build and maintain. Therefore, the materials used in hydraulic and coastal structures are changing from the traditional rubble and concrete systems to the cheaper materials and systems. One of these alternatives employs geotextile tube technology in the construction of coastal and shore protection structures, such as embankment, groins, jetties, detached breakwaters and so on. Geotextile tube technology has changed from being an alternative construction technique and, in fact, has advanced to become the most effective solution of choice. Erosion problems in coastal zones are become increasingly serious due to the development of artificial activities related to the expansion of city functions, industrial complexes and harbour facilities, as well as the removal of sea sand for use in This erosion motion accelerates the regression of the coastal cliff due to the regression of the dunes or the shoreline. In addition, the regression leads to loss of real estate in the hinterland and ruins the shock-absorbing zone between land, and sea. Therefore, the destruction of the dunes may lead to a loss of the habitat or egg-laying grounds of living creatures. In addition, the erosion motion of coastal beach zones destroys the living sites of inhabitants who live in coastal beach zones, and the erosion problem harms the local economy by decreasing the number of visitors. The sea dikes can be easily damaged by the attack of seismic sea wave (Tsunami) due to massive earthquake like the Great East Japan Earthquake in 2011. For these reasons, concern is increasing for the protection of coastal line. Many nations are striving to prevent damage to such zones, as are private organizations and local self-governments. One such preventive effort is beach nourishment or construction of the coast structures. Geotextile containment such as small sandbag has been adopted for the construction of civil structures in the past, large volume geotextile containers are being applied widely in consideration of economical and easy installation, and also for the minimization of environmental effects. Especially, contaminated soil and sediments dredged from port area are utilized to fill in geotextile containment for reclamation. Geotextile containment is widely classified into geotextile bag, geotextile tube, and geotextile containment, and they are filled with soil to be shaped of structure. The filling method is normally hydraulic filling by means of pumping, and also mechanical method can be applied according to the site condition. Thus, Shore erosion is currently causing millions of dollars worth of damage to shorelines and public properties not only along the east coast of Korea but also around the world. Little else needs to be said to emphasize that, without adequate protection, a very significant part of our coastline will fall prey to the ravages of the sea and to man himself.
\end{abstract}

\section{Introduction}

The materials used in hydraulic and coastal structures are changing from traditional rubble and concrete to the environmental materials. One of these environmental materials is the geotextile tube. This material is used to construct coastal and shore protection structures, such as embankments, groins, jetties, detached breakwaters and so on. Geotextile tube technology has changed from being an alternative construction technique to becoming the most effective solution of choice [1]. This paper presents the monitoring and analysis of a stacked geotextile tube structure used as a temporary construction platform of the Incheon Bridge, Republic of
Korea. The Incheon Bridge links the Incheon International Airport (IIA) on Youngjong Island and Songdo New City in Incheon Free Economic Zone (IFEZ)(Fig. 1). The total length of Incheon Bridge is about $21.38 \mathrm{~km}$.

An oval-shaped geotextile tube of less than $2.0 \mathrm{~m}$ diameters was used as a coastal structure for the first time in 1960 [2]. After in 1982, geotextile tubes of $2.0 \mathrm{~m}$ in diameter, made using a strong woven geotextile, were constructed at a coastal area in Brazil. At the same time, non-woven geotextile tubes of less than $1.5 \mathrm{~m}$ in diameter, made from a heavy material, were constructed at a coastal area of Brazil. In 1990, geotextile tubes were used to get a float soil stoke down to the ground.

* Corresponding author: ecshin@inu.ac.kr 
Geotextile tubes of $2.8 \mathrm{~m}$ width and $1.5 \mathrm{~m}$ height were applied to construct in southern Florida, USA. Geotextile tubes of $1.5 \mathrm{~m}$ diameter have been used to preserve the coastal shoreline they have also been as a temporary embankment to protect a dike with reclamation in a coastal area [3]. Recently, geotextile tubes have been used increasingly in marine areas, as a temporary structure like a dike, during bridge constructions to protect the beach line from erosion by sea waves. For the first time in Korea, the geotextile tube was constructed to a height of $1.8 \mathrm{~m}$ to protect the coastal line from erosion. It was installed at Youngjin bay, Korea in 1998 [4]. Then, many of these new tubes were stacked and installed as a temporary construction platform at the Ilsan Bridge construction site and at the Incheon Bridge construction site. In fact, the stability or behaviour of a geotextile tube injected with sand or dredged soil has not been analysed fully. There have been only a few analyses on the groundwater seepage of geotextile tubes after their installation as a temporary large scale structure in the coastal area [5].

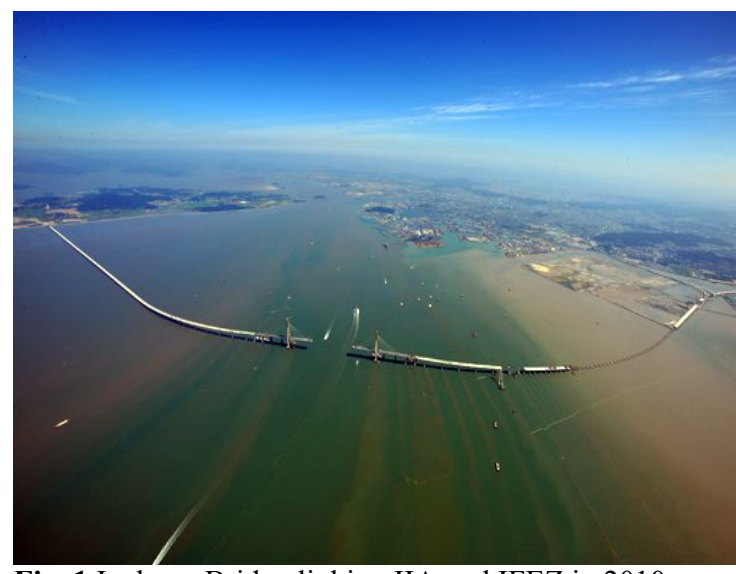

Fig. 1 Incheon Bridge linking IIA and IFEZ in 2010

The stacked geotextile tube technology is being increased as a structure for protecting beach line and as a structure for the purpose of solving the environmental problem. Three types of the geotextile tube were proposed to satisfy the desired crest height, and their stability against external forces was analyzed at each of the cross sections of the stacked geotextile tubes. The considered external forces were wave force, tidal force and lateral earth pressure by reclamation [6].

Also, various field monitoring instrumentations, such as strain gauge, earth pressure cell, pore pressure measurement, inclinometer, were installed at the representative section. The behavior of the stacked geotextile tubes was analyzed using field monitoring results during and after construction.

Stability and seepage affected by the groundwater level based on the tidal datum after the construction was monitored and compared with the results from the numerical analysis. The seepage analysis showed that the seepage in the ground was steady during monitoring. Therefore, when a temporary dike structure is constructed with a filling material, not only should its stability as a structure be considered, but also its height reduction due to settlement by low-pressure filling, scouring by high-velocity tides, and fine - material loss by water flow.

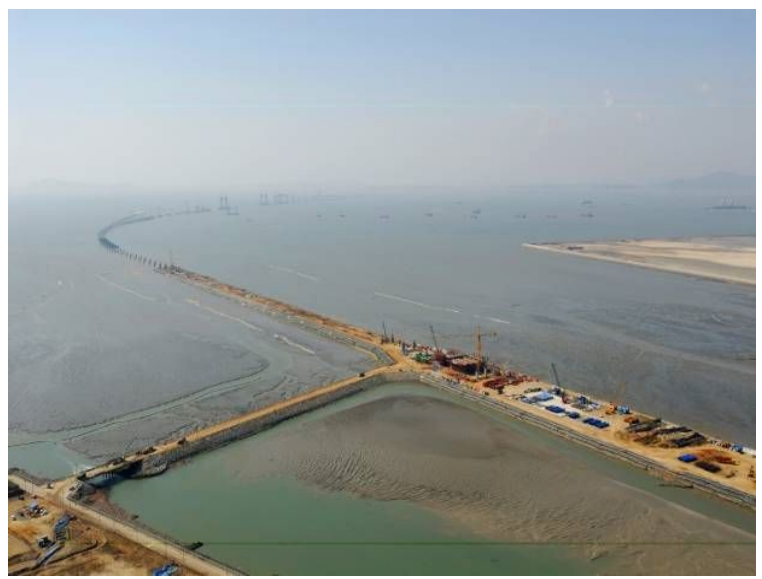

Fig. 2 The Stacked Geotextile Tube of 1,560m long was implemented at the approach Bridge of Songdo New City

\section{Design of geotextile tube}

\subsection{Design of geotextile tube details}

The geotextile tube structure is of permeable fabric form. It is filled with sand or dredged soil from the sea. Its length and diameter have to be designed according to the condition of the construction site. The geotextile tube is delivered to the construction site with a shape of circular. It is filled with dredged material by pumping the mixture of water and soil. If the distance of the geotextile tube between inlet and outlet is far, depending on the condition of the filled material in the tube, so a material like sand can be filled uniformly. A high - permeability fill material cannot be filled up to the desired height of the geotextile tube because there is no pressure inside the geotextile tube. However, it can better conform to the shape of its foundation than a non - permeability fill material. Therefore, a geotextile tube with high permeable fill material has better internal and external stability than a non- permeable fabric form [6].

\subsection{Materials of geotextile tube}

The required properties of the polypropylene geotextile used for making the tube are given in Table 1, as suggested by the US Army Corps of Engineers [7]. The geotextile for the tube can be made from polypropylene or polyethylene. A geotextile tube installed at a field site can be designed with an inner and an outer tube, if required. The inner tube can be made from woven or non-woven polypropylene fabric, which acts as a filter to retain the fine grained material. It is usually needed when the geotextile tube is filled with a dredged material of very fine particles. An outer liner of high strength, woven, polyester fabric is designed to high strength the weight of the fill-material and the pumping pressures required to fill the tube to the required height.

Polypropylene has a higher water permeability than polyethylene. The shape of the tube can construct by filling the material up to $80 \%$ of the diameter as the 
circular structure. If the level of the filling exceeds $80 \%$ of the height of the tube, the friction angle of resistibility may decrease between two tubes. A geotextile tube was designed with consideration of the strength of the geotextile(tensile and seam strength), resistance against long term exposure to UV, resistance against abrasion, tearing strength, punching strength, and flattening behavior of the geotextile tube surface by the consolidation of the inside filling material. Since the geotextile tube was to be installed underwater, uplifting forces like buoyancy had to be considered, in addition to the settlement of dredged soil. A standard geotextile tube was made of woven geotextile sheets of about 4.0 to $5.0 \mathrm{~m}$ width, with inlets and outlets located at regular intervals. Inlets/outlets of about $50 \mathrm{~cm}$ diameter were regularly spaced along the length of the tube at intervals of about $30 \mathrm{~m}$ or more depending on the sedimentation characteristics and the angle of repose of the filled material. The slurry of sand and water at 1:5 ratio was pumped into the tube section, and excess water escaped through the outlets or the geotextile as well as pumped through the outlet pipes attached to the inlets of the geotextile tube.

Table 1. Material Characteristics of Geotextile Tube

\begin{tabular}{|c|c|c|c|c|}
\hline Property & Method & Unit & \multirow{2}{*}{\multicolumn{2}{|c|}{$\begin{array}{c}\text { Standard Value } \\
\text { Polypropylene } \\
\text { (P.P) }\end{array}$}} \\
\hline Composition & & & & \\
\hline Weight & $\begin{array}{l}\text { ASTM } \\
\text { D 5261 }\end{array}$ & $\mathrm{kPa}$ & \multicolumn{2}{|c|}{$6.57 \mathrm{E}-3$} \\
\hline \multicolumn{5}{|l|}{ Mechanical } \\
\hline \multirow[t]{2}{*}{$\begin{array}{l}\text { Tensile Strength } \\
\text { (Wide Width ) }\end{array}$} & \multirow{2}{*}{$\begin{array}{l}\text { ASTM } \\
\text { D } 4595\end{array}$} & $\mathrm{kN} / \mathrm{m}$ & $\mathrm{MD}$ & 196.7 \\
\hline & & $\mathrm{kN} / \mathrm{m}$ & $\mathrm{CD}$ & 196.7 \\
\hline \multirow{2}{*}{$\begin{array}{l}\text { Tensile Elongation } \\
\text { (Wide Width ) }\end{array}$} & \multirow{2}{*}{$\begin{array}{l}\text { ASTM } \\
\text { D } 4595\end{array}$} & $\%$ & MD & 1,000 \\
\hline & & $\%$ & $\mathrm{CD}$ & 18 \\
\hline Burst Strength & \begin{tabular}{|c|} 
ASTM \\
D 3786
\end{tabular} & $\mathrm{kPa}$ & 8,274 & 15 \\
\hline \multirow[t]{2}{*}{$\begin{array}{c}\text { Trapezoid } \\
\text { Tear Strength }\end{array}$} & \multirow{2}{*}{$\begin{array}{l}\text { ASTM } \\
\text { D } 4533\end{array}$} & $\mathrm{kN}$ & $\mathrm{MD}$ & 1.82 \\
\hline & & $\mathrm{kN}$ & $\mathrm{CD}$ & 1.78 \\
\hline Puncture Strength & \begin{tabular}{|l|} 
ASTM \\
D 4833 \\
\end{tabular} & $\mathrm{kN}$ & 1.33 & 1.78 \\
\hline $\begin{array}{l}\text { Factory Seam } \\
\text { Strength }\end{array}$ & \begin{tabular}{|c|} 
ASTM \\
D 4884
\end{tabular} & $\mathrm{kN} / \mathrm{m}$ & \multicolumn{2}{|c|}{98.91} \\
\hline Water Permittivity & \begin{tabular}{|l|} 
ASTM \\
D 4491 \\
\end{tabular} & $\mathrm{Sec}$ & \multicolumn{2}{|c|}{0.10} \\
\hline AOS & \begin{tabular}{|l|} 
ASTM \\
D 4751 \\
\end{tabular} & sieve No. & \multicolumn{2}{|c|}{100} \\
\hline
\end{tabular}

\subsection{External stability of geotextile tube}

The main problems in geotextile tube technology are the lack of proper design criteria for factors such as hydraulic stability and structural functionality and the lack of knowledge of their behaviour during and after construction. In the past, these systems were designed more based on rather vague experiences than on general valid calculation methods. More research, especially on large-scale tests and the evaluation of the performance of projects already realized, is still needed. Recently, new preliminary design criteria supported by model and prototype tests, and some stability analysis calculations have been studied. In general, the hydraulic design criteria have been obtained mainly from hydraulic stability analysis and findings about structural behaviour before/after the construction of geotextile tubes. In this paper, the hydraulic stability analysis based on 2dimensional limit equilibrium theory is briefly described. Geotextile tube structures can fail for many reasons, including sliding, overturning, bearing capacity failure, and migration of the sand in the tube, forces associated with waves (including breaking waves), non-breaking waves, and waves that propagate over the tube. In order to assess the stability of a filled geotextile tube structure, current wave forces have to be estimated. Though a definitive analysis technique has not been established, the modified Minikin approach, as outlined in the U.S. Army Corps of Engineers' Shoreline Protection Manual, may be a reasonable approach for assessing the stability of filled units under wave loading.

In this paper, the theoretical stability analysis employed is a 2-dimensional hydraulic stability analysis, based on linear wave theory and the geotechnical stability analysis method. Several methods for assessing impact loading were addressed by [8-10], and [11]. Hiroi's equation is particularly widely used in Japan and the Asian region. A hydrodynamic pulsating load to a geotextile tube is evaluated by Hiroi's empirical equation as follows:

$$
P_{w}=1.5 \times \rho_{0} \times H_{1 / 3}
$$

where, $\mathrm{P}_{\mathrm{w}}=$ hydrodynamic pulsating load $\left(\mathrm{kN} / \mathrm{m}^{2}\right), \rho_{0}=$ unit weight of sea water $\left(10.0 \mathrm{kN} / \mathrm{m}^{3}\right)$, and $\mathrm{H}_{1 / 3}=$ significant wave height $(2.06 \mathrm{~m}, 10$-year). The following discussion will focus on the safety factor of a geotextile tube against external loading, and the schematic diagram of the 2-D stability analysis is shown in Fig. 3. To simplify the 2-dimensional analysis, the gravitational weight of the geotextile tube was calculated using an equivalent rectangular shaped tube with an effective height. The factor of safety against sliding can be expressed by Eq. 1 .

$$
S F_{\text {sliding }}=\frac{F}{P_{h}}=\frac{P_{v} \times \tan \phi^{\prime}}{P_{w} \times h_{G T}}
$$

Where $\mathrm{P}_{\mathrm{h}}=$ horizontal force, $\mathrm{F}=$ vertical force, $\mathrm{P}_{\mathrm{v}}=$ overburden pressure and gravitational weight of the geotextile tube, $\mathrm{P}_{\mathrm{w}}=$ hydrodynamic pulsating load, $\mathrm{h}_{\mathrm{GT}}=$ effective height $(2.4 \mathrm{~m})$, and $\Phi^{\prime}=$ interface friction angle between the geotextile and the base sand $\left(20^{\circ}\right)$. The factor of safety against sliding of the stacked geotextile tube is 3.7 , considering static hydraulic pressure, and wave pressure of 2.2 . The factor of safety against overturning about the toe of an equivalent rectangular shaped tube can be expressed by Eq. 2 . 


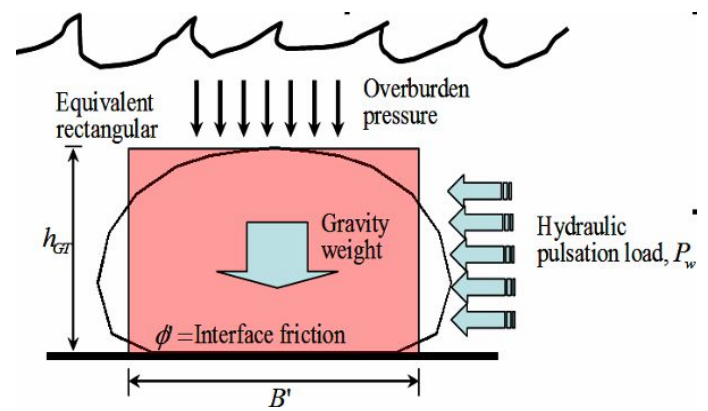

Fig. 3 Schematic Diagram of 2-D Hydraulic Stability

$$
S F_{\text {overtuning }}=\frac{M_{R}}{M_{o}}=\frac{p_{v} \times \frac{B^{\prime}}{2}}{P_{w} \times \frac{h_{G T}}{2}}
$$

Where $\mathrm{B}^{\prime}$ is the width of the equivalent rectangular shaped tube $(4.4 \mathrm{~m})$. The overburden pressure and the gravity weight transmitted to the base soil should be checked against the ultimate bearing capacity of the base soil. The factor of safety against overturning is 6.1 in the stacked geotextile tube under static hydraulic pressure, and wave pressure of 4.4. The factor of safety against bearing capacity failure can be determined by Eq. 4 .

$$
S F_{\text {bearing cupacity }}=\frac{Q_{u}}{Q_{a}}=\frac{c N_{c}+\left(\frac{1}{2}\right) \gamma_{s} B^{\prime} N_{\gamma}}{\frac{P_{w}}{B^{\prime}-2 e^{\prime}}}, e^{\prime}=\frac{P_{w} \times h_{G T}}{3 F}
$$

Where $\mathrm{c}$ is the cohesion of the base soil $\left(25 \mathrm{kN} / \mathrm{m}^{2}\right)$, $\mathrm{N}_{\mathrm{c}}, \mathrm{N}_{\mathrm{r}}=$ bearing capacity factors by the internal friction angle of the saturated base soil, $\gamma_{\mathrm{s}}=$ submerged unit weight of the base soil $\left(8 \mathrm{kN} / \mathrm{m}^{3}\right)$, and $\mathrm{e}^{\prime}=$ the eccentricity of the hydrodynamic pulsating load, as shown in Eq. 1. The factor of safety against bearing capacity failure of the stacked geotextile tube is 8.3 under static hydraulic pressure and wave pressure of 6.4.

Stability analysis was carried out for sliding, overturning and bearing capacity failure for the stacked geotextile tube and the results are tabulated in Table 2 .

Table 2. Stability Analysis for Staked Geotextile Tube

\begin{tabular}{c|c|c|c|c|c}
\hline \multicolumn{2}{l|}{ Overturning(FS) } & \multicolumn{2}{|c}{ Sliding(FS) } & \multicolumn{2}{|c}{$\begin{array}{c}\text { Bearing } \\
\text { Capacity(FS) }\end{array}$} \\
\hline $\begin{array}{c}\text { Static } \\
\text { hydraulic } \\
\text { pressure }\end{array}$ & $\mathbf{3 . 7}$ & $\begin{array}{c}\text { Static } \\
\text { hydraulic } \\
\text { pressure }\end{array}$ & $\mathbf{6 . 1}$ & $\begin{array}{c}\text { Static } \\
\text { hydraulic } \\
\text { pressure }\end{array}$ & $\mathbf{8 . 3}$ \\
\hline $\begin{array}{c}\text { Wave } \\
\text { pressure } \\
\text { (Hiroi } \\
\text { formula) }\end{array}$ & $\mathbf{2 . 2}$ & $\begin{array}{c}\text { Wave } \\
\text { pressure } \\
\text { (Hiroi } \\
\text { formula) }\end{array}$ & $\mathbf{4 . 4}$ & $\begin{array}{c}\text { Wave } \\
\text { pressure } \\
\text { (Hiroi } \\
\text { formula) }\end{array}$ & $\mathbf{6 . 4}$ \\
\hline
\end{tabular}

\subsection{Installation of geotextile tube}

Prior to the installation of the geotextile tube, scour aprons and base polyester mats were deployed on the site that was prepared using grading equipment including a small backhoe. Sand bags were laid on the mats to fix the aprons and mats against the currents. Post pipes of $120 \mathrm{~mm}$ diameter were installed on the seabed ground through the mats so that the geotextile tube could be fastened to them with straps; this fastening of the geotextile tube with the post pipes assured proper alignment during filling. The geotextile tube was supported to the previously installed post piles. Aprons were installed and the tube was deployed in the ebb tide conditions when the seabed was revealed. After installing the geotextile tube, sand was pumped into the tube by the flood tide under water. Injection works were performed under the underwater conditions, or partly submerged conditions.

The geotextile used was $50 \mathrm{~m}$ long and the tube was $5 \mathrm{~m}$ in diameter at the $1 \mathrm{st}$ layer under the submerged condition as shown in Fig. 4 (a). The spacing between an inlet and outlet was $15 \mathrm{~m}$ in this construction. These ports are utilized for filling and also for releasing excess water. Eighty percent of the filling material (U.S.C.S. : SP) was water and the rest was sand. Injection pressure was controlled to less than $30 \mathrm{kPa}$ to prevent tube rupture. To increase the friction between the geotextile tubes, a prefabricated sand mat was used at the interface between upper and lower tubes on the second layer, as shown in Fig. 4 (b). The highest high water level at Incheon is $4.635 \mathrm{~m}$. The tube was elevated to $6.2 \mathrm{~m}$, which is $1.2 \mathrm{~m}$ higher than that of the internal embankment. The geotextile tube was filled with coarse grained sand by hydraulic pumping [12].

\subsection{Monitoring instrument}

The temporary geotextile tube platform was located in the second construction site, with station numbers STA. No.0+000 STA. No. 1+500. The geotextile tube construction site was divided into four sections A, B, C, D. The geotextile tube was installed from $\mathrm{D}$ to $\mathrm{A}$. The planned height of the embankment, which acted as a temporary construction platform, was EL $+6.2 \mathrm{~m}$ and the total length was about $610 \mathrm{~m}$. The geotextile tube site was planned to be used as a foundation site for the main bridge and as a place to make the upper plate of the bridge. The width of the platform was about $33 \mathrm{~m}$, and the width of the platform for the tollgate construction area was about $83 \mathrm{~m}$. The monitoring section for this study was located within the B zone (STA. No.0+600). The first and second layers of geotextile tubes were constructed to have diameters of $5.0 \mathrm{~m}$ the third layer and lastly, the top layer of geotextile tubes was constructed to have diameters of $4.0 \mathrm{~m}$ and $3.0 \mathrm{~m}$, respectively also the layout of the monitoring system and equipment used for measurements are shown in Fig. 5.

\section{Field monitoring of geotextile tube}




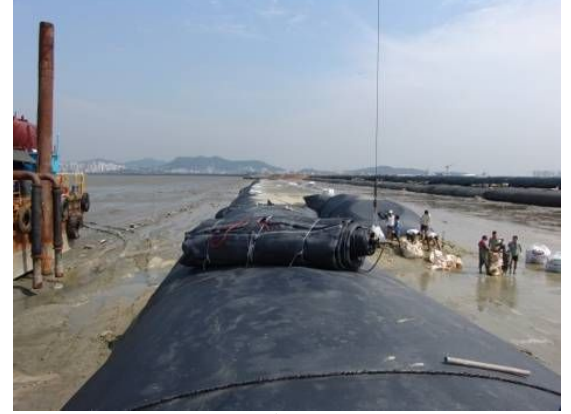

(a) $1^{\text {st }}$ layer

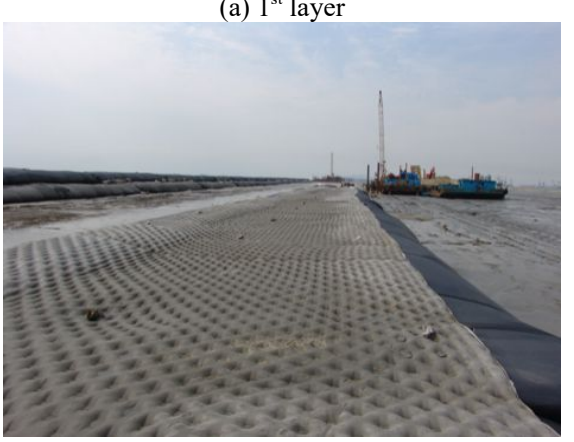

(b) Sand mat

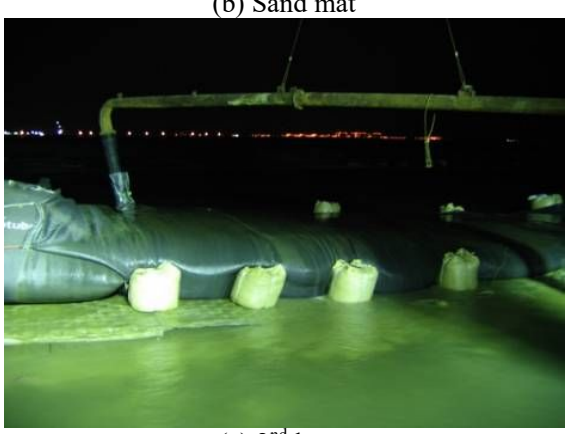

(c) $2^{\text {nd }}$ layer

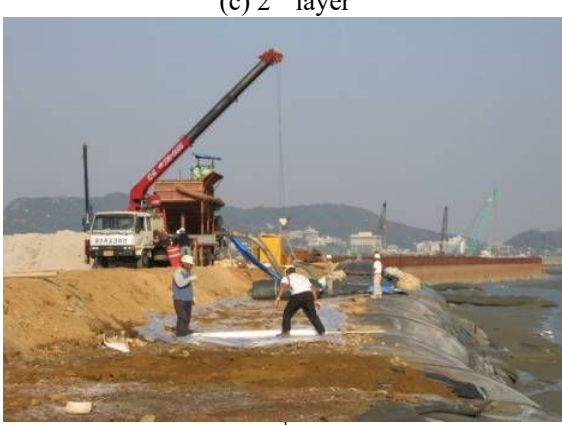

(d) $3^{\text {rd }}$ layer

Fig. 4 Construction Procedure of Stacked Geotextile Tube Construction at Incheon Bridge

Earth pressure, pore water pressure and the lateral displacement strain of the geotextile were measured in the structures of the geotextile tubes. The vertical and horizontal pressures were measured automatically during the construction and after the construction of a geotextile tube. The piezometer was installed into the ground before spreading the geotextiles; it was located at the centre of inside the geotextile tube, on the first layer. In the second and third layers, it was installed in the centre of the inside bottom of the geotextile tube. The elongation gauge was installed in the middle of the side of the geotextile tube where the maximum elongation was expected.

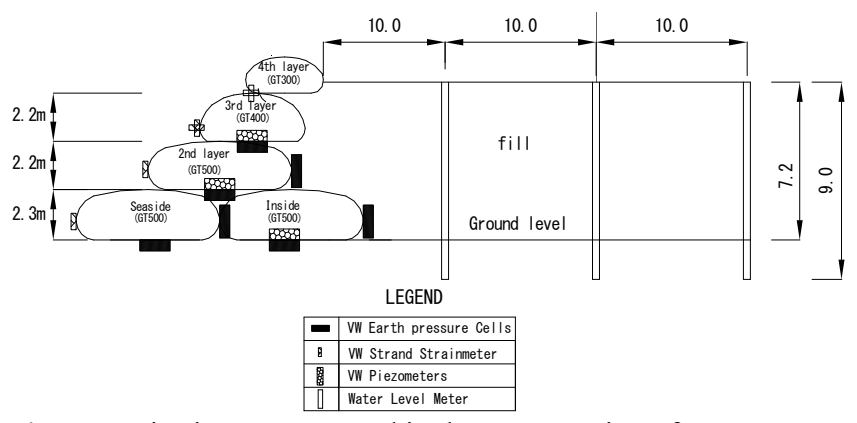

Fig. 5 Monitoring System used in the Construction of a Temporary Platform using Geotextile Tubes

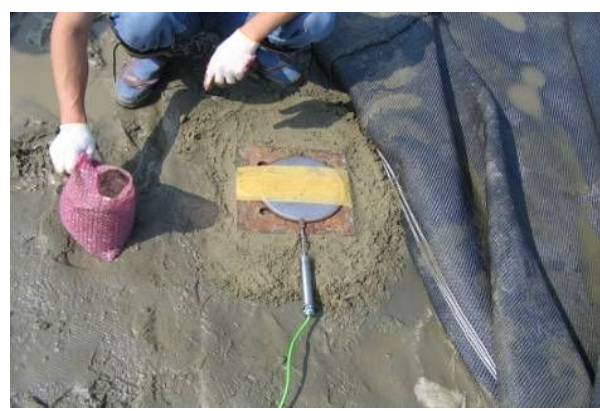

(a) Earth pressure

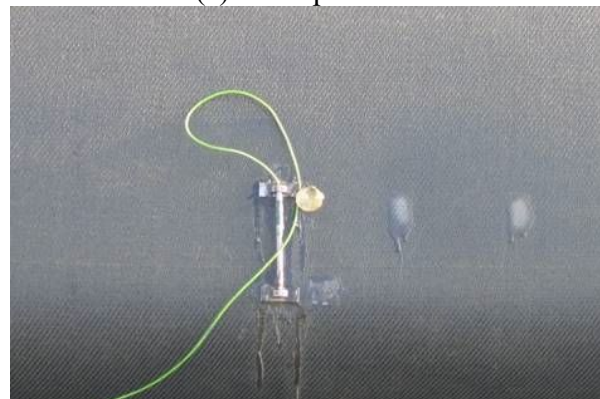

(b) Elongation gauge

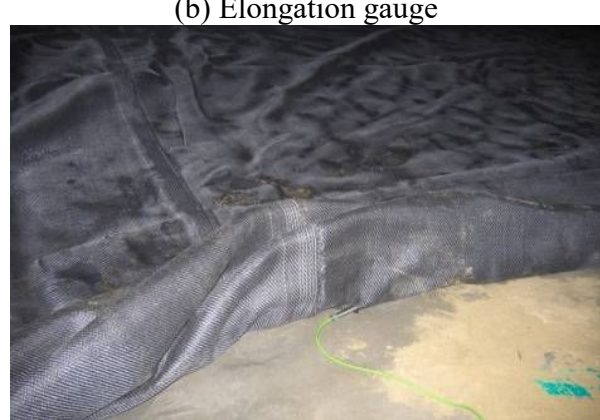

(c) Pore water pressure

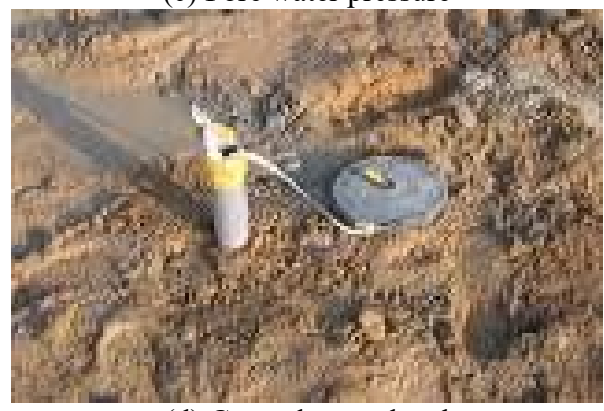

(d) Ground water level

Fig. 6 Installation of Monitoring Instruments in Embankment 


\subsection{The result of monitoring of geotextile tube}

Fig. 7 shows the variation of the earth pressure during the filling of the 2nd layer tube under the underwater condition. Earth pressure in the 1st layer tube was $12 \mathrm{kPa}$ before the beginning of the injection into the 2 nd layer tube and it increased with elapsed time of the filling the sand. Pore water pressure was excluded from this value. Earth pressure at the 1st layer tube after 6 hours of inflations of the 2nd layer tube was $20 \mathrm{kPa}$ and it increased twofold at the end of the filling $(40 \mathrm{kPa})$. Earth pressure beneath the sea-side tube of the 1st layer also changed from $22 \mathrm{kPa}$ to $51 \mathrm{kPa}$.

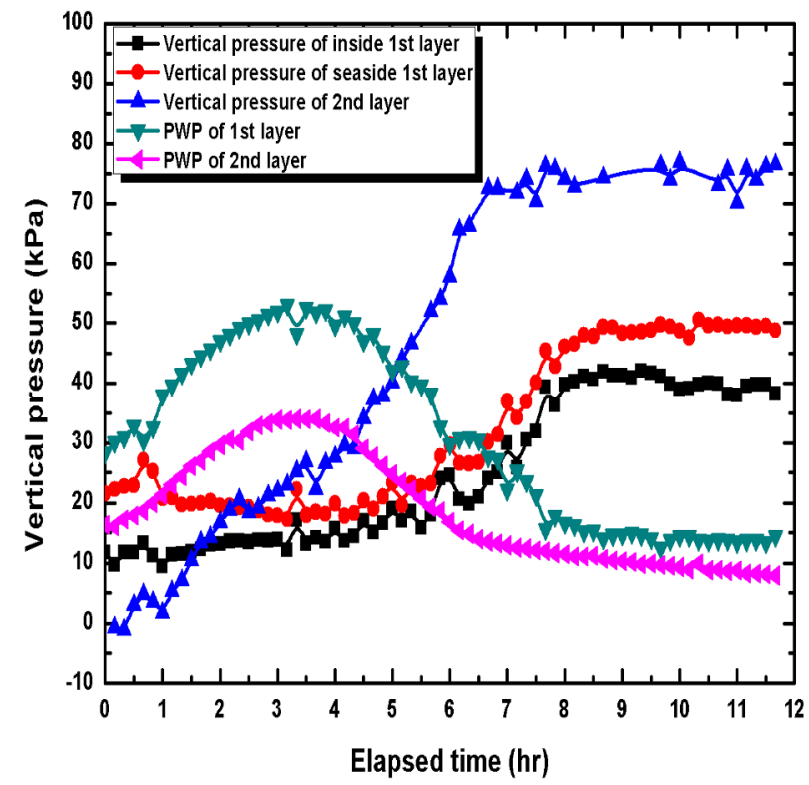

Fig. 7 Vertical Pressure during Installation under the Sea

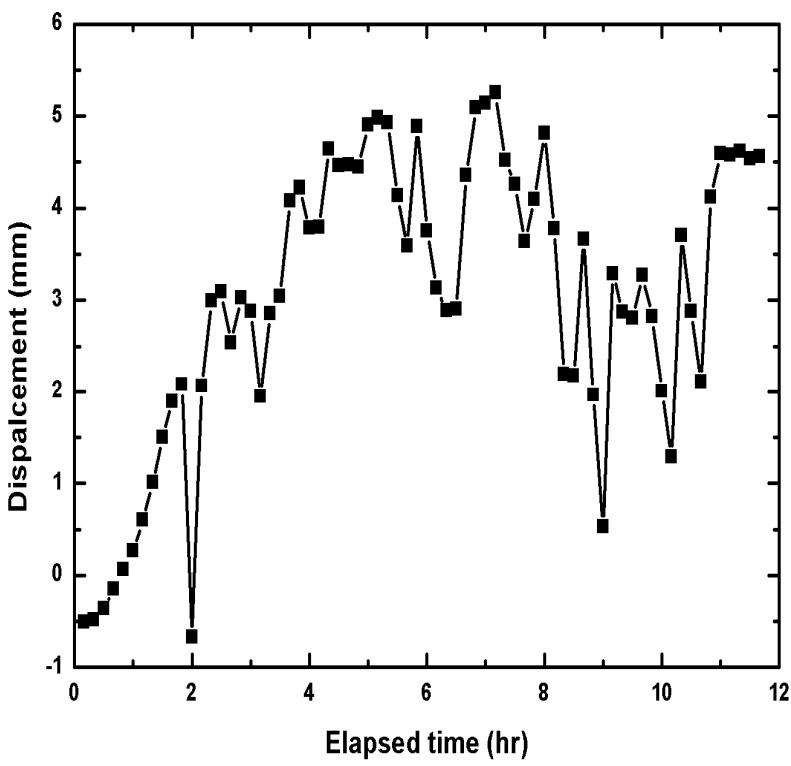

Fig. 8 Variation of Elongation during Geotextile Tubes Installation with Elapsed Time at the 2nd layer

A pressure of $78 \mathrm{kPa}$ was measured beneath the 2 nd layer tube after the pumping into the tube and Fig. 8 indicates that this pressure was distributed to the $1 \mathrm{st}$ layer tubes. The maximum strain was measured at the middle part of the tube in the circumferential direction. Axial strain along the tube shaft was $70 \%$ of the circumferential displacement, and the approximately $5 \%$ of the total displacement was reduced during 6 months after the installation.

\section{The case of field construction}

\subsection{Design and construction of containment bund using geotextile tubes in Singapore}

In a major port development project located in the southern part of Singapore, 16 additional berths are being constructed at Pasir Panjang Terminal, Singapore (shown in Fig. 9) to cope with the trade boom here. The Maritime and Port Authority of Singapore (MPA), which oversees the development of port developments here, stated that this expansion project would increase the annual handling capacity of this port to 14 million standard containers. As part of this port expansion project, a containment bund is needed for the purpose of containing any sediment plumes that might arise from other construction activities. This bund would prevent the sediment plumes from being transported towards the Labrador Nature Reserve by the eastward-going current. In addition, this bund also acts as earth retaining structure to retained dumped/dredged material during the construction period.

The type of containment bund proposed is a geotextile containment bund, which consists of geotextile containers and tubes being stacked systematically to form the structure under marine conditions. For the successful application of geotextile containment bund, the geotextile containers and tubes that are installed have to attain a high level of accuracy and tolerance defined. According to Pilarcyzk (2000) and Lawson (2006), a geotextile tube is a tubular container that is formed in-situ, on land or in water, by hydraulically filling the tube with sand or dredged material. Geotextile tubes range in sizes, from $1 \mathrm{~m}$ to $10 \mathrm{~m}$ in diameter, and the length can be as long as the project requires. Geotextile container is a form of containment unit that is made of geotextile sheet which is then filled mechanically with sand, clay, or dredged material. These large containers are sewn to sizes as required for a particular project. The empty geotextile container is laid in a split barge, and subsequently filled with soil from the top opening. After filling, the top opening is sewn to form into a closed "container". The barge will then move to the desired position and the bottom of the barge will open, allowing the containers to sink into the sea, at the intended position. The volume of these containers usually ranges from $100 \mathrm{~m}^{2}$ to $800 \mathrm{~m}^{2}$. In this project, the tube used is a large volume tubular shape that is being filled on barges, and then subsequently dropped into the submarine environment. To avoid confusion, the geotextile tube method used in this project would be referred to Modified Geotextile Tube (M-GT) 


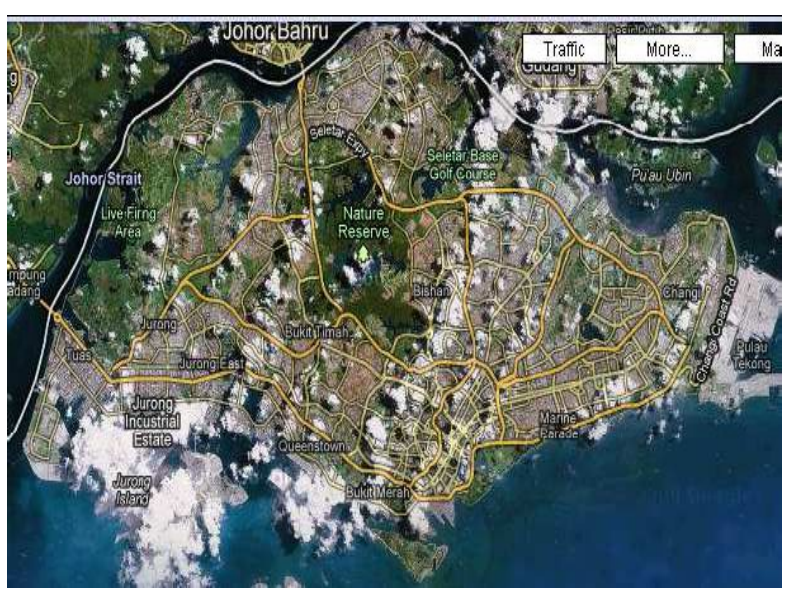

Fig. 9 Location of the project site in Singapore

\subsection{Geotextile tubes as submerged dykes for SHORELINE in Malaysia}

The Malaysian shoreline is in excess of $4800 \mathrm{~km}$ and a large portion of this comprises of sandy coasts. Sandy shorelines dominate the east coasts of Peninsular Malaysia and occupy a significant portion of the coasts of Sabah and Sarawak. The Economic Planning Unit (1985) reported that about $30 \%$ of the Malaysian shoreline suffers from erosion, with a high percentage of the eroded areas largely along the shoreline of Peninsular Malaysia. Development of coastal areas to serve important economic and social needs often interferes with natural processes to the extent of causing the shoreline to respond differently and to alter the erosion and accretion patterns. Erosion of coastal lands in Malaysia has reached an alarming stage and the number of problem sites has increased over the last 12 years. The consequences of coastal erosion are severe in Malaysia as much of the economic and social life of Malaysia depends on activities in its coastal areas. Many of these activities are served by facilities that have either already been damaged or will be damaged in the near future. The affected activities include agricultural community life, recreation, transportation, and tourism. Worldwide climatic changes have resulted in significantly increased incidences of shoreline erosion and effective control measures are necessary to protect these shorelines.

Teluk Kalong in the district of Kemaman in Terengganu, Malaysia has encountered erosion of the shoreline. A case study of the shoreline protection measure in a pilot project at Teluk Kalong is discussed. Pantai Batu Buruk is located in Kuala Terengganu, the capital city of the state of Terengganu in Malaysia. The shoreline is exposed to the direct impacts of severe storms, especially during the North-East Monsoon periods, causing widespread erosion. The result of the continuous erosion had created a sandy beach which, however, is not conducive to beach users, particularly with the steepened beach profile. The second case study in this paper describes the shoreline protection measures at this beach front and the results of preliminary performance assessments carried out as shown in Fig. 10.

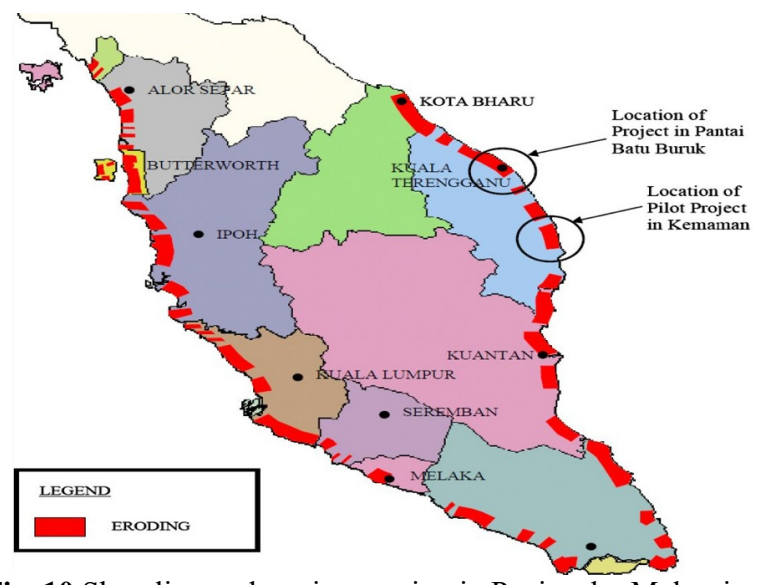

Fig. 10 Shoreline undergoing erosion in Peninsular Malaysia (EPU, 1985)

Structural control measures have been employed in the past throughout Malaysia. The measures used are generally designed to harden and armour selected areas against wave attack as well as the use of groynes to trap sediments and alter long-shore transport. These include rock revetments, concrete-faced bunds and dykes, and rock-filled or concrete groyne structures. Examples of these are indicated in Fig. 11 Fig. 15. The erosion problems in Malaysia have resulted in the construction of over $60 \mathrm{~km}$ of revetments. Even with this effort, continuous erosion still persists, paving the way for a search of alternative forms of protection.

The function of the revetment structure is to prevent the loss of shore sediment and to limit wave run-up from overtopping the structure. Wave run-up is reduced by the roughness of the revetment surface and the size of the rocks is determined by wave height. Soil bearing capacity will determine the strength of the foundation support of the structure. Commonly, a layer of geotextile is incorporated into the revetment structure as a filter and separator.

Common causes of failure to these hard structural measures are undermining of the toe, excessive settlement, failure due to lateral movement, overtopping and flanking. Failure of filter system will also result in excessive loss of materials behind the structure and may result in an excessive settlement

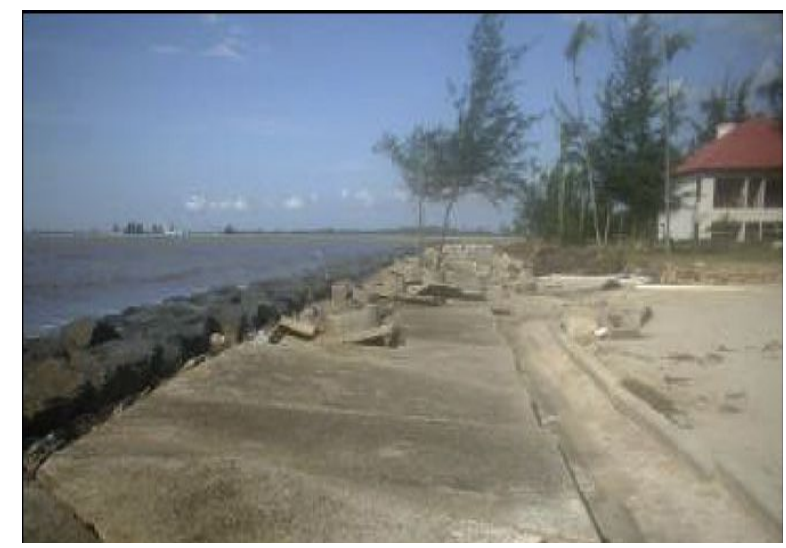

Fig. 11 Concrete units used for erosion protection 


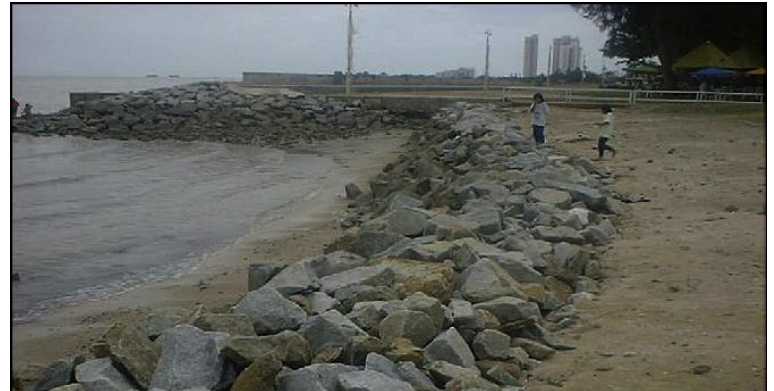

Fig. 12 Rock revetment used for erosion

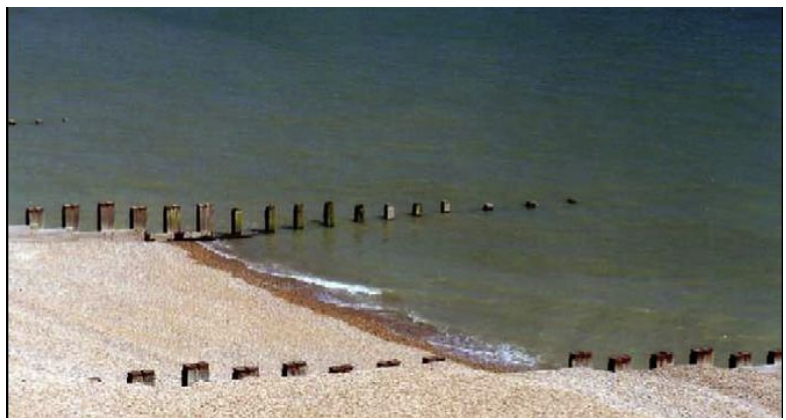

Fig. 13 Concrete groyne structures protection

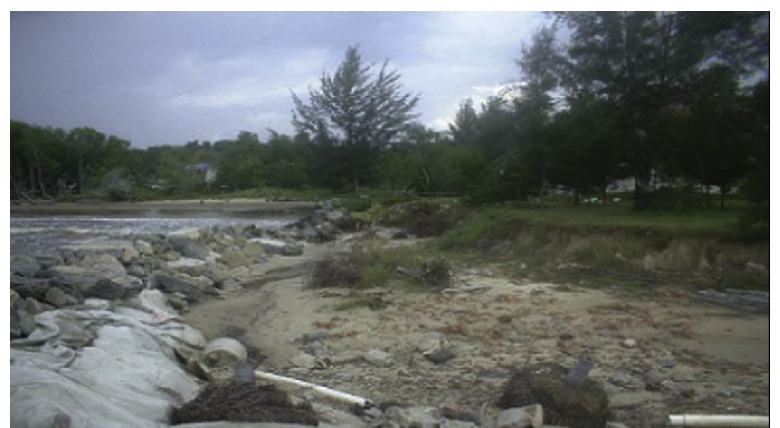

Fig.14 Failure of protection measure protection

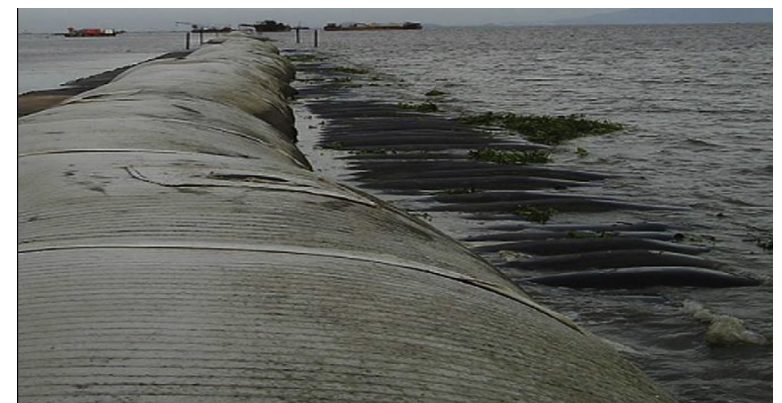

Fig. 15 Geotextile tube used for coastal protection works

\subsection{Case study no. 1: pilot project at Teluk Kalong, Kemaman, Terengganu}

The shoreline along the coast of Teluk Kalong is composed mainly of granular sandy materials. These sediments are easily erodible when subjected to wave forces and if not adequately protected. A length of about $500 \mathrm{~m}$ in length of this existing shoreline had been exposed to severe erosion, resulting in instability of the existing seawall, which consisted of precast concrete slabs as shown in Fig. 16. Fig. 16 shows the severity of the shoreline erosion and the strength of the waves approaching the shoreline. Loss of sandy materials behind the concrete panels due to severe erosion had resulted in large and uneven settlements of the panels. The condition of the beach front was also not suitable for recreational activities due to the rather narrow and steep foreshore area. A pilot project was initiated in 2006 by the Public Works Department to remedy the situation by using the geotextile tube as a submerged dyke. The design concept for the coastal erosion protection and beach enhancement is to use a system of geotextile tubes sitting over a layer of apron mattress, as shown in the typical cross section in Fig. 17. The inner structure of these geotextile tubes consists of high strength woven polypropylene geotextile with ultimate tensile strengths of $150 \mathrm{kN} / \mathrm{m}$ in warp and weft directions. An outer layer of nonwoven polypropylene geotextile having the ultimate tensile strength of $40 \mathrm{kN} / \mathrm{m}$ in the machine and cross-machine directions were stitched onto the inner reinforcement layer, to increase the durability of the tube due to abrasion and ultra-violet degradation. The fabrics are all tested for compliance to high seam strengths in excess of $80 \%$ of the ultimate tensile strength.

These geotextile tubes were installed for a total length of $500 \mathrm{~m}$ along the beach front. The design requirements adopted for the development of the system included: (a) The geotextile tubes are to be sited at approximately $150 \mathrm{~m}$ from the shoreline, (b). The geotextile tubes shall be totally submerged at low tide condition, with a freeboard of $1 \mathrm{~m}$.

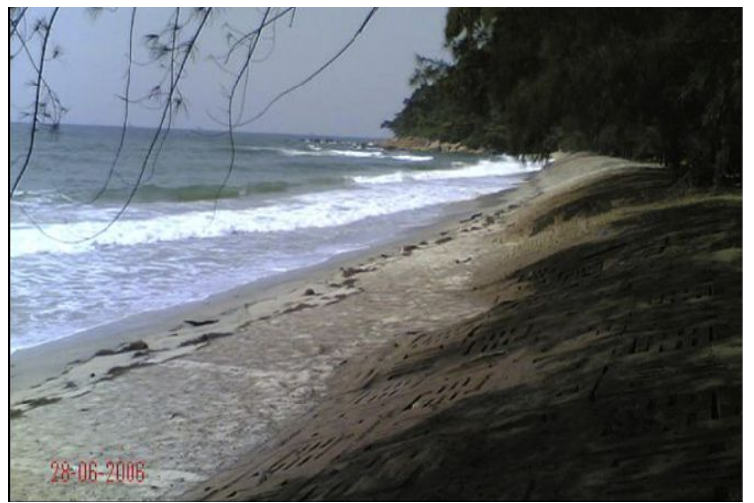

Fig. 16 The condition of shoreline before application geotextile tube protection works (June 2006)

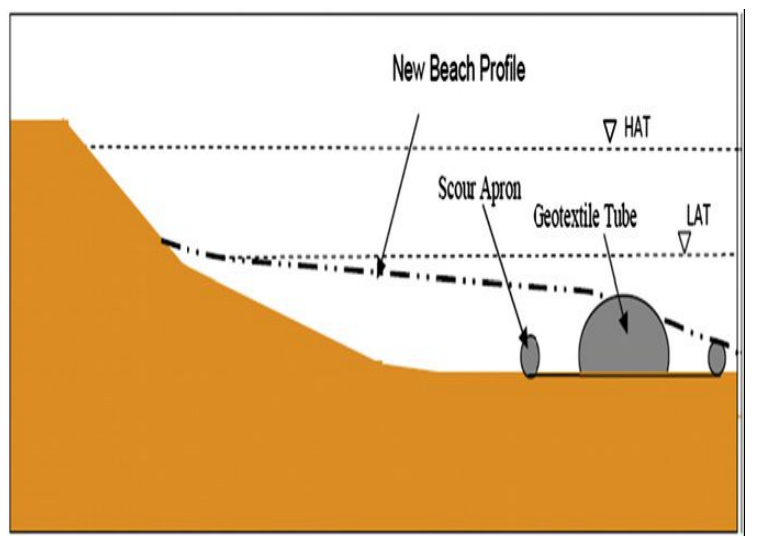

Fig. 17 Cross section of the design concept 


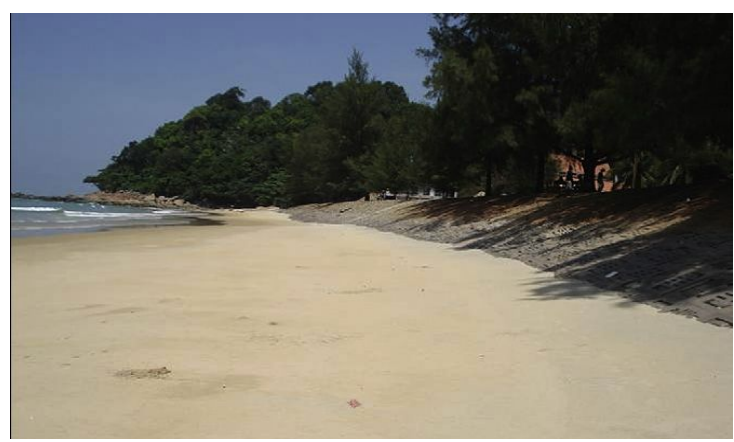

Fig. 18 The condition of shoreline and beach in December 2009 after completion of submerged geodykes installation

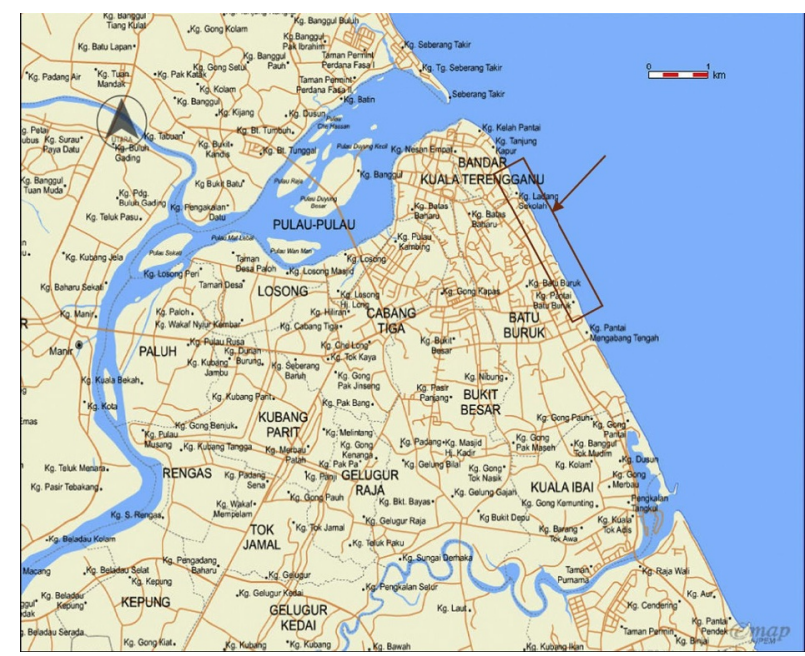

Fig. 19 Location of Pantai Batu Buruk in Kuala Terengganu

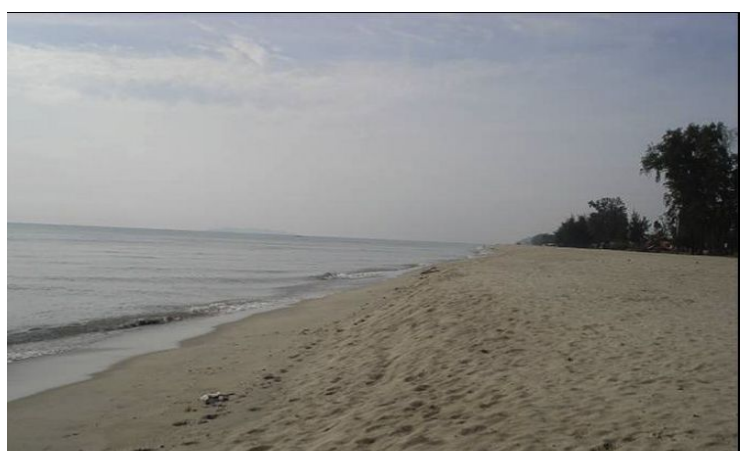

Fig. 20 View of the beach at Pantai Batu Buruk (June 2008)

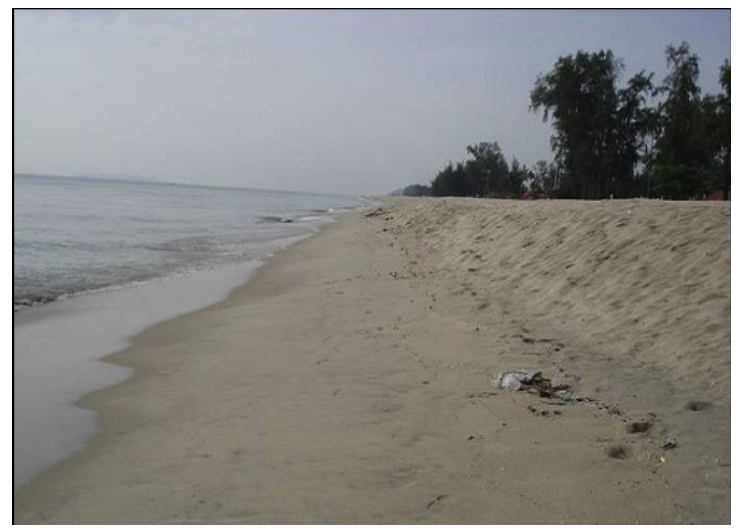

Fig. 21 View of the beach at Pantai Batu Buruk (June 2008)

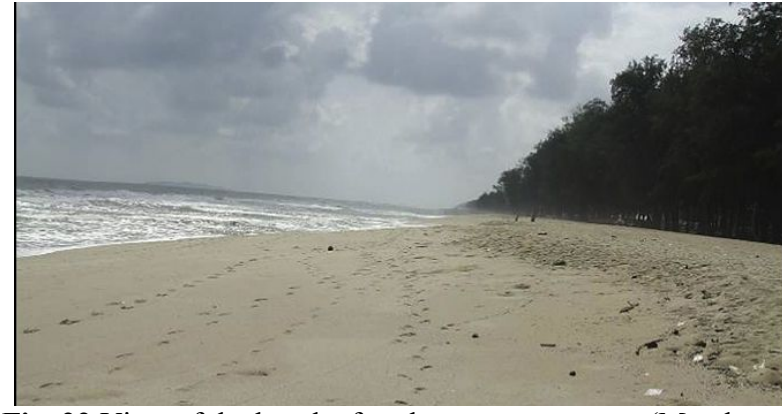

Fig. 22 View of the beach after the monsoon storm (March 2009)

\section{Conclusions}

The design process of a geotextile tube was reviewed and the stacking procedure of geotextile tubes was presented, with the evaluation of their stabilities in terms of sliding, overturning, and bearing capacity. The geotextile tube was monitored in the field with measurements of earth pressure, pore water pressure, and strain of the geotextile tubes.

The field monitoring results of the stacked geotextile tubes were similar to those obtained from the numerical method. The monitored earth pressure under a fully injected geotextile tube was about $40 \%$ of the predicted value. The height of the inflated tube did not exceed $50 \%$ of the original diameter and the ground subsided as the injection proceeded. However, the monitored earth pressure beneath the 2 nd layer tube was $130 \%$ of the predicted value because of the load concentration on the centerline and the small settlement of the 2nd tube. Therefore, when a temporary dike structure filled with a material is constructed, not only should its structural stability be considered, but also its height reduction due to settlement by conditions such as low pressure filling, ground scouring by high-velocity tides, and fine material loss by water flow. Case studies of geotextile tube application have been proved to be very effective for construction of sea dike and protection of shore line from erosion by sea wave attack.

\section{References}

1. Adam Bezuijen and EW Vastenburg, "Geosystems, design rules and applications", CRC Press/Balkema, (2013)

2. Carroll, R. P., "Submerged Geotextile Flexible Forms using Noncircular Cylindrical Shapes", Geotech. Fabrics Rep., IFAI, St. Paul, MN, Vol. 12, No. 8, pp. 4-15, (1994)

3. Shin, E. C., Oh, Y. I., Kang, J. K., Kim, S. H., "Behavior Analysis of Multilayer Geotextile Tubes Dike at Inshore Reclamation", Proceedings of Korean Geosynthetics Society, pp. 127-137, (2007)

4. Shin, E. C., Oh, Y. I., "Construction Monitoring of Geotextile Tube at Young-Jin Bay and Stability Analysis by Hydraulic Model Tests", Journal of Geotechnical Engineering Conference, Korean Geotechnical Society, pp. 549 - 556, (2002) 
5. Shin, E. C., "Behavior of Geotextile Tube Composite Structure by 2-D Limit Equilibrium and Plane Strain Analysis", Journals of Korean Geoenvironmental Society, Vol.7, No. 6, pp. 13-22, (2006)

6. Leshchinsky, D., Leshchinsky, O., Ling, H. I. and Gilbert, P. A., "Geosynthetics Tubes for Confining Pressurized Slurry: Some Design Aspect", Journal of Geotechnical Engineering, ASCE, Vol. 122, No. 8, pp. 682-690, (1996)

7. Goda, Y., Random Seas and Design of Maritime Structures, University of Tokyo Press, Tokyo, Japan, (1985)

8. Hiroi, "Evaluation of Wave Pressure", Journal of JSCE, Vol. 6, No.2, pp. 435-449, (1920)

9. Honma, M., Horikawa, K., "Experimental Study on Total Wave Force against Sea Wall", Coastal Engineering in Japan, Vol. 11, No. 6, pp. 119-129, (1965)

10. Minikin, R.R.), "Winds, Waves, and Maritime Structures: Studies in Harbor Making and in the Protection of Coasts", 2nd ed, Charles Griffin, London, (1963)

11. Cho, S. M., Jeon, B. S., Park, S. I., and Yoon, H. C., "Geotextile Tube Application as the Cofferdam at the Foreshore with Large Tidal Range for Incheon Bridge Project", Geosynthetics in Civil and Environmental Engineering, pp. 591-596, (2009). 